\title{
Role of Retail Price Strategy in Influencing Customer Purchase Intention
}

\author{
P. Saritha, Karanam Satish Kumar, Shaik Abdul Mazeed
}

\begin{abstract}
Price sensitivity was consistently a matter of worry for retailers when planning pricing strategies. The expectant reaction towards changing price is high felt among the middleclass purchasers and impact more on their purchasing decisions in India. This research plans to decide, regardless of whether the estimating special technique for the key-esteem classification, acquires a huge change in the offer of key-esteem things or not. The examination is decisive and applied the quantitative method to approve the proposed speculation. An organized poll comprising 21 inquiries was utilized to gather information through an online review. The Snowball inspecting strategy was utilized to gather information from respondents, including youthful workers, homemakers, and entrepreneurs, and gathered reactions towards the incessant value limits offered by driving hypermarkets chains and general stores in the country. The straight relapse is directed utilizing SPSS programming. Discoveries of the exploration presumed that as the Indian center section is exceptionally evaluated touchy, henceforth tremendous value limits impel brand agitating among them and even impact the pre-purchasing choice for procurement. The significant limitations of the examination were that it centered uniquely around contemplating the effect of cost special proposals on deals which is exceptionally relevant and restricted to item classes, wherein there are different factors additionally which can altogether affect deals. We have decided the effect of one develop over another under the shadow of key-esteem classifications, while further exploration can check the effect separately or on different classifications too. The exploration is absolutely experimental and directed interestingly by the analyst to imply the significance of value advancement procedure in consonance to deals. The newly gathered essential information utilized for approval.
\end{abstract}

Keywords: Price Promotional Strategy, Key Value Category,

\section{INTRODUCTION}

In the present situation, Indian retail has created as quite possibly the most energetic industry with a lot quicker speed as a result of the passage of the new players. According to IBEF, (2019), India expects the retail industry to take care of business as US $\$ 1,200$ billion industry by 2021, in contrast with US\$689 billion and fifth most favored objective among worldwide retail customers.

Manuscript received on May 21, 2021.

Revised Manuscript received on May 28, 2021.

Manuscript published on May 30, 2021.

* Correspondence Author

Dr. P. Saritha, Assistant Professor, Dept. of Business Management, Yogi Vemana University, YSR Kadapa (AP), India.

Karanam Satish Kumar, Assistant Professor of H \& S Dept., SRIT, Aanthapuramu (AP), India.

Shaik Abdul Mazeed*, Assistant Professor, Dr. B. R. Ambedkar Institute of Management and Technology, Baghlingampally, Hyderabad (Telangana), India. Email ID: mazeed22@gmail.com

(C) The Authors. Published by Blue Eyes Intelligence Engineering and Sciences Publication (BEIESP). This is an open access article under the CC BY-NC-ND license (http://creativecommons.org/licenses/by-nc-nd/4.0/) Key Value Items, Sales, Retailers.

Over all utilization a cost which was US\$ 1,824 billion of every 2017 expected to reach almost US\$3,600 billion by 2020, accounting10 percent of the nation's Gross Domestic Product (GDP) and around 8\% of the business. Retail is developing the business with a lot quicker speed in the Indian market. India is one of the quickest developing key economies in the Asian Continent. The nation goes under the political and financial consortium of the Continent having a mass market of the center worker. The retail area has been one of the quickest developing portions set apart by the presence of practically all large public retailers such as Big Bazaar, Reliance Fresh, Hyper city etc. A portion of the relevant characters among industry players both in staple and non-basic food item fragments are its developing rivalries and viewing for estimating procedures. Over the most recent couple of many years, the Indian economy has raised out of its engaged consideration by its market structure, expanded drivers for utilizations, type of revenue, way of life, and infrastructural offices. This prompted the premium of numerous global players to create cutthroat showcasing procedures. The impulsive purchasing conduct to a great extent impacted by factors like market-based economy, access, and accessibility of a wide assortment of merchandise, accessibility of simple credit offices, and significant degree of extra cash and adequate roads of shopping from all the four promoting blend factors, estimating has been utilized as one of the significant devices for making a learned example reaction in the cerebrum of the clients. Today the circumstance is more extreme because of the wild rivalry among the retailers through changing value offers and low value techniques. Sufficient proof was there to confirm that items are imprudently bought more when having low value driving towards urgent purchasing conduct. The retail market is currently defying with exceptional culmination as the quantity of players is more, having practically equivalent firm size having shadowed separation between the item/brand classes. Hereafter Indian retailers are thinking about changing estimating technique as one of the significant device/weapons to trigger the deals, embracing both cutthroat valuing and limited evaluating as a system. The client store decision altogether affected by the cost offered by the retailers, making valuing issue as most strategical piece of business action for retailers. The lowvalue rebate offered by retailers may draw in every one of the clients on the lookout and just ease participants can contend with the value heroes. At last estimating methodologies, value limits are utilized often by every one of the retailers in the country. Over and over received value limits offers proceeded with the extension of the retail area with more quantities of outlets that can outfit recurrent higher force of cutthroat tension on retailers.

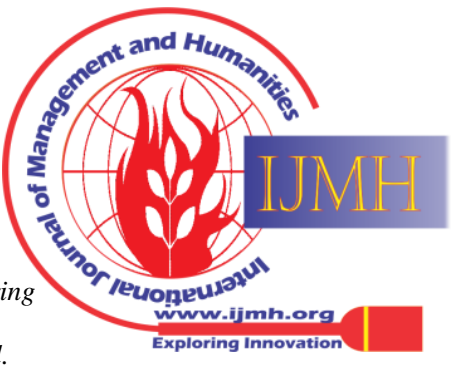

Blue Eyes Intelligence Engineering \& Sciences Publication (C) Copyright: All rights reserved. 
These exercises further lead to substantial limits keeping up portion of the overall industry and complete benefit because of lower edges. The value limits received by the significant stores and hyper-markets focuses towards the way that the cost has been scaled down to an exceptionally low level to create a greater cost flexibility so the clients get pulled in towards the retailer fundamentally due to the fascination of lower costs as it were. This estimating technique has changed the buyer conduct of those clients that have a place with working class sections in India.

\section{LITERATURE REVIEW}

Stearns (2020): Consumers of today are more open to a context regarded by the individual style owning customized and specialty showcasing the industrialism gets profound established in the nation because of the startling progression of hotspots for money as startup BPO's, Migration of provincial customer to metropolitan, and so forth has made an interchange among otherworldly and nationalistic qualities and the prevailing fascination towards realism as demonstrated by the utilization example of the nationals. The disposition towards consumption influenced by the richhelpless separation, rustic metropolitan setting.

Stearns (2019): Shopping is a significant relaxation action in the country for nationals just as for the migrants and is one of the significant subjects of conversation between individuals than some other theme. The newbies are inculcated into this framework purposely through direction visits zeroing in on shopping centers, hypermarkets, and grocery stores. The connection among commercialization and expanded promoting endeavors have been followed each other throughout the previous 300 years as it found that there existed a connection between the advancement of advertising channels and strategies one next to the other with the improvement of industrialism during the eighteenth century in Western Europe.

Zinkhan (2018): Consumer scientists have tracked down a causal connection among industrialism and special endeavors, particularly through promoting by organizations.

O Guinn and Faber (2017): Many exact investigations have demonstrated that materialism gets advanced by sitting in front of the TV and TV promoting. Advertisers' endeavors are engaged and focused towards the making of impulsive purchasing which is characterized as "persistent, redundant buying that turns into an essential reaction to adverse occasions or sentiments". These variables are particularly predominant in our country. The acceleration of hypermarkets, general stores, shopping centers, and so on give adequate roads to the customers to snatch the items that they like to purchase and the monetary organizations rouse them to buy more by giving credit offices as Master cards, advances, and so forth the 4Ps in showcasing has extensive impact on buy. The significant items that are bought by individuals are garments; adornments, shoes, food things, family articles, and so on and all worldwide brands are accessible in every one of the hypermarkets, stores and shopping centers in bounty. The players dispatch substantial limited time movement by offering hefty limits; get one get one free offer, coupons. Dissemination is covered everywhere on the country through retail organizes that range from huge hypermarket ideas to little smaller than usual business sectors.
Agardite and Bauer (2016): Among the other 4P's of the advertising blend, cost possesses a significant part in supporting the purchasing choices for buyers. Cost is one of the significant expenses possessed by the customers, notwithstanding other enthusiastic expenses. Additionally, the cost is one of the costs that can be effectively definite by the customers, and thus it turns into a significant measure for customers while making advertising methodologies.

Narasimhan, Nesli, and Sen (2015): cited that it isn't required that cost related advancements probably won't spur drive purchasing. Advertisers apply weighty value limits for their retail shops expect to attract customers for a particular product or category anticipating to get a reference from the clients later on for shopping. Weighty cost discounts were done to assemble an impression among shoppers causing them to accept that the retailer chose by them is a pioneer in limits. At the point when buyers buy the item at a low value, it turns into a reference evaluating for retailers for what's to come.

Mazumdar, Raj, and Sinha (2014): value taxi be classifications into two sorts, inside reference cost, and the outer reference cost. Inner cost is framed when purchaser recollections the last cost at which buy was made and subsequently it is subject to the memory of the customer and past buy insight and the outside reference cost is reliant upon outer natural factors, for example, value motivator offered by the merchant.

Mazumdar's and Palatal's (2013): examines demonstrate that both interior and outer reference value impact are buying with fluctuating levels of impact dependent on varieties in the market sections.

Zeroes and Haneberg, (2012): Designing valuing technique are consistently logical to the way that what is happing on the lookout. Getting Market and appropriate market examination drive to better estimating methodologies extraordinarily while alluding this for working class mass purchasers. Discussing different estimating methodologies like the maximum methodology, serious evaluating, markdown valuing buyers are frequently slanted or actuated by value rebate technique. Additionally, for retailers of stores and hypermarkets value rebate advancements are to a great extent used to scale deals of comfort products.

Mullin and Cummins (2011): expressed that value advancements incorporate cash off coupons, pence off streaks, get one get one free and additional fill packs.

Indeed, even Yushin (2010): Noted that value delicate clients are more mindful of special exercises and effectively partake in looking for cost limited time offers.

Madan and Suri's (2009): brought up in their exploration, that cost rebate can have adverse outcomes on advancements, focuses on that retail enterprises have been utilizing changed types of cost techniques like transient cost limits and the most famous and effectively utilized cost promotion to rejuvenate deals and increment momentary interest for their items and administrations. This isn't huge in the Indian setting as mass working class generally lean towards limits in cost.

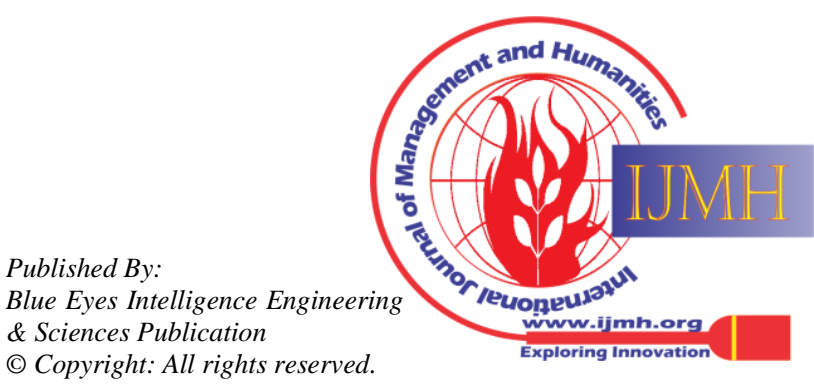



classifications which have more noteworthy significance for building client value picture then others. In some cases, Key Value Categories go about as influencers to intrigue client's discernment at the cost. In any case, there is the likelihood that with a given profundity of variety and regular changes in estimating procedures client may get confounded or incapable to review the value correlation for all items, and thus she/he may allude to the comparative item classification called as Key Value Items. utilizing high-low valuing methodology typically do profound value advancements of items which can possibly draw in an enormous number of purchasers in the store. In spite of the fact that their goal is that a large portion of those shoppers will purchase different items on normal costs, available are available careful choosers, customers who investigate and look at retailer's offers and purchase on elite value offers. Regularly then retailers with generally greater cost picture, most basic hello lo retailers, have the best costs available for specific items. These briefly low costs, along with a low-value picture of specific classes at various retailers is one of the reasons for careful selectors appearance.

Gorgio (2006): as attested that the buy expectation and buy choice by purchasers is a perplexing cycle and is influenced by different interior factors just as outer variables. The buy goal and ensuing buy choice relies on the apparent worth of an item. Seen esteem relies upon the contrast between the booking cost of the purchaser (RPB) and the reservation cost of the vender (RPS).

Heitman, Lehmann, and Herrmann (2005): RPB is the most extreme value that the purchaser will pay, and RPS is the base value that the vender needs to acknowledge after the deal. The RPB is driven by the client through publicizing, verbal, value advancements. The RPS typically relies upon the expense of the item that the dealer sells. Consequently, the cost is quite possibly the main factors that influence the buy choice if the items offered by every one of the retailers are of a similar brand and quality.

\section{METHODOLOGY}

The present research study is decisive and applied the quantitative strategy to approve the proposed speculation. An organized poll comprising of 21 inquiries was utilized to gather information through an online overview. Snowball examining technique was utilized to gather information from respondents, including youthful workers, homemakers, and entrepreneurs and gathered reaction towards the successive value limits offered by driving hypermarkets chains and stores in the country. The essential study directed from September 2020 to March 2021. Family with a normal pay of Rs. 50,000/- to Rs. 1,00,000/- each month is haphazardly chosen for the investigation. The sample size taken is directed with a snow ball sampling technique. The information on clients' purchasing propensity for ten fundamental consumable items, amount astute just as shopwise, were gathered for examination. In any case, by choosing ten driving retailers, Big Bazar, Hyper city, Reliance Fresh and M\&S, the examination was conducted in
Chime and Latin (2008): Reportedly there are not many

Hamilton, and Cherney (2007): Mostly retailers

Hyderabad. A hyperlink to the online survey was shipped off 345 respondents through email, and the respondents were additionally mentioned to advance the poll to their companions, associates, and family members. The information assortment measure was completed from November 2020 to March 2021. An aggregate of 335 legitimate reactions were gotten showing a reaction pace of 44.9per penny, which was sensible for investigations of this scale. 49.3 of the respondents were females, and 50.7 percent were guys. Out of the complete example, $37 \%$ were youthful workers, 31.9 percent was entrepreneurs, and 32.6per penny were housewives. The example is a marker gathering to test the exploration model as retail outlets/shopping centers are mainstream among understudies and homemakers. In addition, working experts exorbitantly utilize the retail source for internet shopping while at work.

Hypothesis: H01: There is no connection between cost limited time system intended for Key Value Categories (KVC) and the deals of Key Value Items (KVI).

H02: Price Promotional Strategy fundamentally affects the deals of those items, which were not recorded in the value rebate offer. Cost Promotional Strategy decidedly related with the inclination to buy on Visa on the lookout.

\section{Cost Promotional Strategy (Independent Variable)}

In the investigation, value rebate system is the autonomous variable, and the deals were considered as a reliant variable. The free factor is additionally classified into five sub factors as nitty gritty underneath:

1. Size of the Price Discounts.

2. Inward/External Price Referencing.

3. Item Categories.

4. Kind of cost limited time technique.

5. Span/Timing of cost limited time offers.

\section{Sales (Dependent Variable)}

The value markdown procedure is affecting the deals, and consequently, the accompanying elements were taken as sub-factors.

1. Buy Decision.

2. Acquisition of different Products.

3. Buy on Credit Facilities.

Optional information gathered from the sites of the retailers, a data set kept up by them identified with deals and value changes, different diaries of the board, business magazines, different sites, and other related sources like neighborhood papers. The examination investigates the effect of cost rebate advancement on the general deals of the relative multitude of significant grocery stores and hypermarkets by connecting cost markdown offers with the volume of deals, deals were connected to factors, for example, rehash buy choice, expansion in the amount requested of different items in the retail outlet other than the limited items, Visa buy. By taking the client traffic in the retail outlets and the volume of deals, the examination has taken seven significant driving general stores and hypermarkets Big Bazaar, Reliance Fresh, Hyper city.

Published By:
Blue Eyes Intelligence Engineering \& Sciences Publication (C) Copyright: All rights reserved.

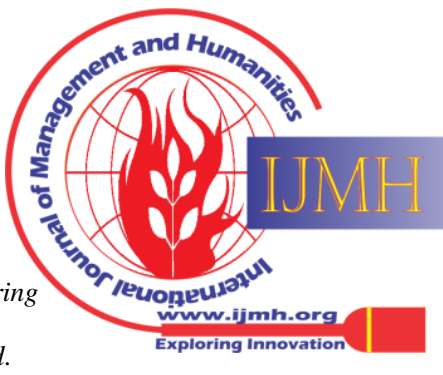




\section{ANALYSIS \& RESULT}

Table 1: Means values of the various elements in sales performance

\begin{tabular}{|l|l|}
\hline $\begin{array}{l}\text { Sales (Variable- } \\
\text { Dependent) }\end{array}$ & $\begin{array}{l}\text { Arithmetic Mean } \\
\text { Values }\end{array}$ \\
\hline Intention to purchase & 4.169 \\
\hline Products Demand & 4.213 \\
\hline Credit Purchases & 3.986 \\
\hline
\end{tabular}

Table-1shows the consequences of the information gathered through the survey from the example respondents. The table shows the mean upsides of the reliant factors that reflect changes in the acquisition of the buyers. The mean worth of value rebate advancement on buy choice and interest for different items addresses the critical effect of the value advancement plot on buy expectations. While the mean worth of credit buys addresses that credit buy influences the buy recurrence of brand yet not to that degree as value rebate impacts deals.

Table-2: The correlation coefficient between price promotion offers and sales.

\begin{tabular}{|c|c|c|c|}
\hline Price Promotions & Intention to repurchase & Other products Demand & Purchase through Credit Card \\
\hline Discount on Price & .346 & .367 & .358 \\
\hline Referral Pricing & .398 & .482 & .389 \\
\hline Categories of Products & .276 & .278 & .245 \\
\hline Promotional Strategy & .354 & .385 & .403 \\
\hline Time Period of offers & .396 & .369 & .376 \\
\hline
\end{tabular}

Correlation level of significant at the 0.01 level.

The effect of value rebate advancement on deals advancement was anticipated in table- 2 by utilizing numerous relapse investigation. The investigation results show that the effect of value rebate advancement clarifies about $47 \%$ varieties in the business execution of the retailers as $\mathrm{R} 2=.47$. The investigation additionally uncovers that there exists a positive connection between cost markdown advancement and the expansion in deals volume at retail. Table-2 likewise addresses the relationship between the value markdown offers of the general stores and hypermarkets and its effect on their business execution at a $1 \%$ huge level. Table 2 shows that there exists a positive relationship between the different components of cost limited time exercises of the organizations and the business volume created by it through repurchase, interest for different items Mastercard buy, and recurrence of procurement. Thus, this discovering upholds the whole three proposed theories. Commercialization is firmly embedded among the working-class families in the country by incessant value advancement offers by the retailers. Table2 shows the relationship between the value markdown offers of the stores and hypermarkets and its effect on their deals at a $1 \%$ critical level. The table shows that there exists a positive relationship between the different components of cost special exercises of the organizations and the deals created by it Size of the Price Discounts, Internal/External Price Referencing, Product Categories, Type of cost limited time procedure, Duration/timing of cost special offers. Industrialism is emphatically embedded among the workingclass families in the country by incessant value advancement offers by the retailers.

\section{FINDINGS}

The examination has uncovered the accompanying bits of knowledge into the utilitarian connection between the value rebate offers and the buys by the working-class Indian. The buying conduct of working-class families was unequivocally affected by the value rebate offers or value advancement projects of the retailers in India. The recurrence of value limits offers more as they decidedly sway the recurrence of visits by the purchasers pulled in towards the retail outlet. Individuals are persuaded to buy a greater number of numerous wares which are not expected to them when there is a value markdown offer for specific items which are key-esteem things. The value rebate offers are spread by the retailers through different media at first, however, it triggers an ensuing second flood of publicity through informal, which is a likely component in making a significant degree of mindfulness among individuals about the advancement during a brief period. Certain retailers embrace value limits so that a low-value administration was made which thusly turns into a reference value point for the clients.

\section{CONCLUSION}

The motivation behind the examination was to decide the effect of changing the valuing procedure on the client buy choice. The information was separated from 335 respondents from the age gathering of 20 to 55 years, out of which 49.6 per penny and 50.4 percent females and guys individually, addressing Hyderabad. Out of the complete example, 37\% were youthful workers, 31.9 percent were entrepreneurs, and 32.8 per penny were housewives. The noticeable perceptions made in the exploration were that value advancement/rebate conspire essentially affects the buy choice of the client. Credit offices likewise sway buy aim, yet not with the solid force as value markdown accomplishes for deals. The investigation has uncovered a couple of experiences into the practical connection between the value rebate offers and the buys by the working-class Indian in the given locale.

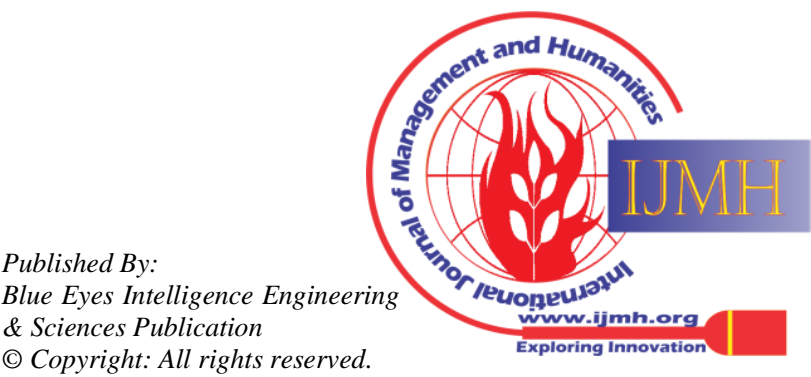


Right off the bat, the buy conduct of working-class families is unequivocally impacted by the value rebate offers or value advancement projects of the retailers. Additionally, the recurrence of value limits offers is more as it emphatically impacts the recurrence of visits by the purchasers pulled in towards the retail outlet. It is been seen during research that the clients are inspired to buy a greater number of numerous wares which are not expected to them when there is a value rebate offer for specific items which are key-esteem things. Thirdly it was likewise seen that retailers embracing value markdown offer genuinely began claiming the low-value administration making reference value point for the clients. Retailing is one of the exceptionally encouraging and impending exercises in India, wherein the presence of practically every one of the worldwide players was emphatically felt now. The market has changed into a profoundly aggressive one with every one of the highlights of a defectively cutthroat market that looks like the serious structure of Michael E. Watchman. The inner cutthroat contention has become so solid that the current retailers are creating different systems to shield their turf. In their work to hold and build the portion of the overall industry, value rebate offers have become a them by making apparent increases to them through different cost markdown offers and projects. The paper gives adequate understanding into the many-sided connection between the value markdown offers and the volume of deals execution by the retailers, which is observationally demonstrated by considers directed by Bucklin et al (1998) advertisement Li et al (2007) by underscoring the way that value limits consistently spur families to switch and buy sooner than arranged. This paper has given smart experiences to retailers to design cutthroat estimating methodologies to pull in and hold client unwaveringness. Credit advance offices have expanded the buying force of clients.

\section{REFERENCES}

1. Alford, B. L., \& Biswas, A. (2002). The effects of discount level, price consciousness and sale proneness on consumers' price perception and behavioral intention. Journal of Business research, 55(9), 775-783.

2. Arnold, S. J., Oum, T. H., \&Tigert, D. J. (1983). Determinant attributes in retail patronage: seasonal, temporal, regional, and international comparisons. Journal of Marketing Research, 20(2), 149-157.

3. Aviv, Y., \&Pazgal, A. (2008). Optimal pricing of seasonal products in the presence of forward-looking consumers. Manufacturing Service Operations Management, 10(3), 339-359.

4. Bell, D. R., \&Lattin, J. M. (1998). Shopping behavior and consumer preference for store price format: Why "large basket" shoppers prefer EDLP. Marketing Science, 17(1), 66-88.

5. Black, D. W. (2007). A review of compulsive buying disorder. World Psychiatry, 6(1), $14 . \quad$ Retrieved from https://www.unido.org/sites/default/files/2006-10/mrak_0.pdf

6. Chen, S. F. S., Monroe, K. B., \& Lou, Y. C. (1998). The effects of framing price promotion messages on consumers' perceptions and purchase intentions. Journal of retailing, 74(3), 353-372.

7. D'Andrea, G., Schleicher, M., \&Lunardini, F. (2006). The role of promotions and other factors affecting the overall store price image in Latin America. International Journal of Retail \& Distribution Management, 34(9), 688-700.)

8. Drozdenko, R., Jensen, M., \& Coelho, D. (2011). Pricing of green products: Premiums paid, consumer characteristics and incentives. International Journal of Business, Marketing, and Decision Sciences, 4(1), 106-116.

9. Gogoi, B. J. (2013). Study of antecedents of purchase intention and its effect on brand loyalty of private label brand of apparel. International Journal of Sales \& Marketing, 3(2), 73-86.

10. Grewal, D., Monroe, K. B., \& Krishnan, R. (1998). The effects of price-comparison advertising on buyers' perceptions of acquisition habitually applied apparatus to pull in the clients and hold

value, transaction value, and behavioral intentions. Journal of marketing, 62(2), 46-59.

11. Heitmann, M., Lehmann, D. R., \& Herrmann, A. (2007). Choice goal attainment and decision and consumption satisfaction. Journal of marketing research, 44(2), 234-250.

12. Hamilton, R., \&Chernev, A. (2013). Low prices are just the beginning: Price image in retail management. Journal of Marketing, 77(6), 1-20.

13. IBEF, (2019). Indian Retail Industry Analysis. February 2019. Retrieved from https://www.ibef.org/industry/indian-retail-industryanalysis-presentation.

14. Madan, V., \& Suri, R. (2001). Quality perception and monetary sacrifice: a comparative analysis of discount and fixed prices. Journal of product \& brand management, 10(3), 170-184.

15. O'Guinn, T. C., \& Faber, R. J. (1989). Compulsive buying: A phenomenological exploration. Journal of consumer research, 16(2), 147-157.

16. Leszczyc, P. T. P., Sinha, A., \&Sahgal, A. (2004). The effect of multipurpose shopping on pricing and location strategy for grocery stores. Journal of Retailing, 80(2), 85-99.

17. Lichtenstein, D. R., Ridgway, N. M., \&Netemeyer, R. G. (1993). Price perceptions and consumer shopping behavior: a field study. Journal of marketing research, 30(2), 234-245.

18. Zeithaml, V. A. (1988). Consumer perceptions of price, quality, and value: a means-end model and synthesis of evidence. Journal of marketing, 52(3), 2-22.

19. Zerres, C., \&Huenberg, R. (2011). Price promotions in the automotive trade: price knowledge and information expenditure as factors influencing the perception of benefits. The market, 50 (2), 109-120.

20. Narasimhan, C., Neslin, S. A., \& Sen, S. K. (1996). Promotional elasticities and category characteristics. Journal of marketing, 60(2), 17-30.

21. Mirabi, V., Akbariyeh, H., \&Tahmasebifard, H. (2015). A study of factors affecting on customers purchase intention - Journal of Multidisciplinary Engineering Science and Technology (JMEST), 2(1).

22. Mazumdar, T., Raj, S. P., \& Sinha, I. (2005). Reference price research: Review and propositions. Journal of marketing, 69(4), 84-102.

\section{AUTHORS PROFILE}

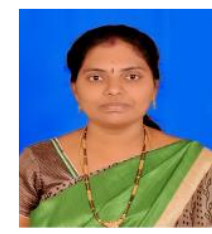

Dr. P. Saritha, Assistant Professor, Department of Business Management, Yogi Vemana University, Kadapa-516005 E-mail: sarithamsg@yahoo.co.in she is an eternal student dedicated to teaching and learning. She was awarded Ph.D from SV University, Tirupati in the year 2008 with the specialization of Finance and Marketing. She was also completed her Technical course of HWC (Honors Diploma in Web Centric Computing) from NIIT, Kadapa in the year 2003 including C, C++, Java, Oracle, Tally and MS-Office. She has Three Nationally published books and One Internationally published book from VDM Publications, Mauritius. She has 50 articles published in various National, Scopus, International reputed and referred journals with the impact factor between 1-5.947 and 40 papers published in National, and International edited books. She was attended and presented 100 papers in National and International Seminars/workshops/symposiums in India through online and off-line mode. She is a life member in All India Accounting and Commerce Association (AIACA), New Delhi. She has worked in different administrative positions in YVU such as Coordinator for UG/PG Examinations, Co-coordinator of Placement Cell, Associate Director in Directorate of Admissions, Coordinator of MD Cell (Management Development Cell), Program Officer for NSS, Advisory member in College Development Council(CDC) and NSS University Level Advisory Committee, member in steering and core committee for preparing SSR for NAAC Accreditation and member in Innovations and Credits and Industry Collaborations Committee for creating A.P. knowledge hub, Warden YVU Women's Hostels and member in IQAC in Govt. College for Men, Kadapa. She has been acted as an Editorial Board member and Reviewer for various International Journals like AJBM, IRJMH, IJLIS, IJETMAS. She has organized various National and International Seminars, Conferences, Workshops and Webinars as a Convener and Co-convener in Yogi Vemana University, Kadapa.

Published By:

Blue Eyes Intelligence Engineering DOI:10.35940/ijmh.I1320.055921

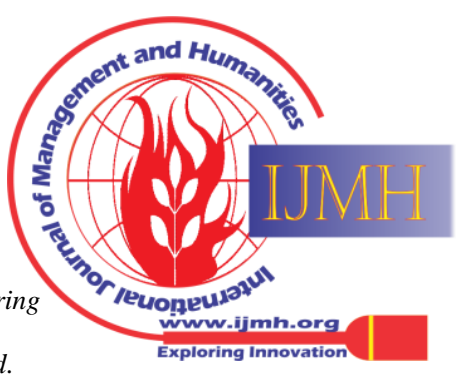




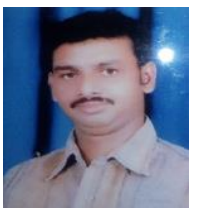

Karanam Satishkumar, Assistant Professor, H\&S

Department, Srinivasa Ramanujan Institute of

Technology, Ananthapuramu, Andhra Pradesh 515701 e-mail: satishpcp@gmail.com

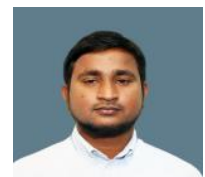

Shaik Abdul Mazeed, MBA, APSET, (Ph.D.) Working as an Assistant Professor in Dr. B. R.

Ambedkar Institute of Management and Technology, Baghlingampally, Hyderabad. He has a decade experience in Teaching, Research and Industry. Presently he is pursuing his Ph. D from Yogi Vemana University, YSR Kadapa, Andhra Pradesh.

He holds MBA degree with a dual specialization in Human Resources Management and Finance from Osmania University. His areas of interests are Operations, Finance and HR. He has more passion in publishing research articles. He published 13 research papers in Scopus-Indexed journals. Besides he has 33 articles to his credit which are published in various national and international journals/conferences. Apart from teaching, he held several administrative positions like, Coordinator-ED Cell, Coordinator for Patents and Copyrights, in charge Exam branch.

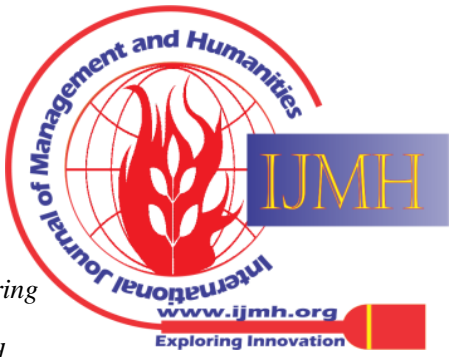

